\title{
POLLUTION INDEX AND ECONOMIC VALUE OF VANNAMEI SHRIMP (Litopenaeus vannamei) FARMING IN INDONESIA
}

\author{
Ofan Bosman*\#, Tri Edhi Budhi Soesilo*), and Sinung Rahardjo* \\ *) School of Environmental Science, Universitas Indonesia, Indonesia \\ Jl. Salemba Raya No. 4, RW.5, Kenari, Senen Sub-District, Jakarta, Indonesia \\ *) Jakarta Technical University of Fisheries, Indonesia \\ Jl. AUP Pasar Minggu, Jakarta, Indonesia
}

(Received: February 8, 2021; Final revised: March 30, 2021; Accepted: March 30, 2021)

\begin{abstract}
Shrimp farming has contributed a large share in Indonesia's aquaculture portfolio for at least a decade, and a national plan to increase shrimp production by $250 \%$ has been recently laid out. However, boosting shrimp productions could lead to unintended consequences in environmental and socio-economic negative impacts. The rapid development of vannamei farming in Java has increased coastline land clearings and demands of fertilizers, feeds, and chemicals to sustain the farming activities. Such pressures will eventually lead to a reduced environmental capacity and the farming efficiency itself. This study aimed to study the environmental impacts and business performance of intensive shrimp farming in Indonesia. The study was conducted in Aquaculture Business Center (ABC) in Karawang for four months, from July to October 2020. In-situ and ex-situ measurements of water quality parameters were done at six sampling stations directly post-harvest water discharge. The measured parameters consisted of temperature, $\mathrm{pH}$, dissolved oxygen, ammonia $\left(\mathrm{NH}_{3}\right)$, nitrite $\left(\mathrm{NO}_{2}\right)$, nitrate $\left(\mathrm{NO}_{3}\right)$, phosphate $\left(\mathrm{PO}_{4}\right)$, alkalinity, and salinity. Pollution Index (PI) was used as the primary method to determine the environmental impacts of the shrimp farming. The R/C Ratio was used to analyze the business performance of the company. The results showed that the water quality index in the $A B C$ area was categorized as lightly polluted in station 1 (Plj 4.52) and station 5 (Plj 4.37), moderately polluted in station 2 (Plj 6.24), station 3 (Plj 6.72), and station 4 (Plj 6.13) and heavily polluted in station 6 (Plj 111.06). The determined $\mathrm{R} / \mathrm{C}$ ratio was 1.10, meaning that the shrimp farming is classified as economically profitable. Although the shrimp farming's economic performance value is very good, the water conditions affected by waste from the shrimp pond culture will reduce the $R / C$ ratio in the future if not properly managed.
\end{abstract}

\section{KEYWORDS: pollution index; water quality; vannamei; R/C ratio; environment}

\section{INTRODUCTION}

According to the Food and Agriculture Organization (FAO), Indonesia is the second-largest farmedshrimp-producing country in ASEAN, slightly behind Vietnam (FAO, 2018). Indonesia's highly valued farmed shrimp is exported to international markets, contributing to Indonesia's significant foreign revenue (Hadie $\&$ Hadie, 2017; Tran et al., 2017). Farmed shrimp products from Indonesia are mainly exported to the United States, Japan, and the European Union. In 2016, farmed shrimp production in Indonesia ranked third globally with 644,000 tons (FAO, 2018). It was slightly below Vietnam in second with 694,400 tons and China as

* Correspondence: School of Environmental Science, Universitas Indonesia, Indonesia. JI. Salemba Raya No. 4, RW.5, Kenari, Senen Sub-District, Jakarta, Indonesia.

E-mail: ofan.bosman@ui.ac.id the top producer of 1.600 .000 tons (FAO, 2018). According to the Indonesian National Statistical Data in 2019, farmed shrimp commodity led the national fishery export products within the last five years (2013-2017). It grew at an average of 6.43\%per year within the period (BPS, 2019).

Aquaculture is the fastest-growing food production system globally, bringing potential solutions and new challenges for marine and coastal sustainability (Partelow et al., 2018). Aquaculture contributes 44.1\% of the total world's fish supply of 167.2 million tons with an annual increase rate of $8 \%$ (Jayanthi et al., 2018). Considering Indonesia has enormous potential resources with a total indicative land area of 17.2 million hectares suitable for aquaculture, it is estimated that aquaculture could contribute a direct economic value of 250 billion USD per year (KKP, 2018). 
The Indonesian government launched a revised target of increasing vannamei shrimp exports by $250 \%$ in 2024 (Kemenko Marves, 2020; KKP, 2020). This revised target means that the total value of farmed vannamei has to reach IDR 90.30 trillion (USD 6.45 million) by 2024 from IDR 36.22 trillion (USD 2.58 million) in 2019. In terms of production volume, the total shrimp production should increase from 517,397 tons in 2019 to 1,290,000 tons in 2020. As part of the effort, the Indonesian Coordinating Ministry of Maritime and Investment released a program to increase vannamei farming areas to 86.000 hectares until 2024 (Kemenko Marves, 2020).

As a result, shrimp farming has caused concerning socio-economic and environmental impacts (FAIRR, 2019; Galappaththi \& Berkes, 2015; Mitro et al., 2014; Saha, 2017). For example, the Ministry of National Development Planning (BAPPENAS) in 2014 reported that many aquaculture business entities in Indonesia have not yet implemented Good Aquaculture Practices (Bappenas, 2014). The increase in landbased shrimp farming activities will eventually lead to the clearing of mangrove forests, increased use of feeds, fertilizers, and inappropriate application of chemicals that can negatively impact the environment (Boyd, 2003; De Lacerda et al., 2006; Tarunamulia et al., 2016).

In Bengkalis Kembung River, Indonesia, a massive shrimp pond development had degraded the water quality of the adjacent rivers in from of increased $\mathrm{BOD}_{5}$, nitrate $\left(\mathrm{NO}_{3}\right)$, and phosphate ( $\left.\mathrm{PO}_{4}\right)$ values (Harianja et al., 2018). In other areas of Indonesia, such as in Kawaru Beach and Losari Subdistrict, the establishment of vannamei ponds has changed the coastal landscape (Pinto, 2016) and increased the likelihood of harmful algal blooms (HABs) occurrences (Tarunamulia et al., 2016). In Andulang village-Sumenep East Java, Indonesia, the rapid development of shrimp ponds has impacted nearby agricultural land and released ammonia pollutants to the adjacent coastal area (Hidayatillah, 2017). Also, high protein feed in shrimp culture can release nitrogen pollutants and organic matter to the surrounding waters (Imamah et al., 2013).

The contradicting features of shrimp farming (its impact on the environment but profitable as a business) have attracted global attention from various stakeholders such as academics, practitioners and private businesses. In most cases, research related to shrimp cultivation have reported massive negative impacts of shrimp farming on the environment (Páez-Osuna, 2001). A new approach needs to be developed that strikes a balance between producing a high yield of shrimp and maintaining the quality and function of the environment. Therefore, this research aimed to analyze the environmental impacts and link them to the business performance of an Indonesian shrimp farming system.

\section{MATERIALS AND METHODS}

\section{Research Site}

The research was carried out for four months from July to October 2020 at vannamei ponds owned by the Aquaculture Business Center ( $A B C$ ) in Karawang Regency-West Java, Indonesia.

\section{Research Data}

Water samples were collected at six stations, namely mixed channel $A(1)$, mixed channel $B(2)$, seawater receptacle (3), Ciwadas River (4), Cimunclak River (5), and outlet channel (6) (Fig 1). The water samples were collected shortly after the ponds' water was discharged post shrimp harvest. In-situ measurements of water quality parameters were temperature (YSI 550A-SNI 06-6989.23-2005), pH (pH meterSNI 06-6989.11-2004), dissolved oxygen (YSI 550ASNI 06-6989.14-2004), and salinity (refractometer). Exsitu measurements of water quality parameters were ammonia $\left(\mathrm{NH}_{3}\right)$ (Spektrofotometer-SNI 06-6989.302005), nitrite $\left(\mathrm{NO}_{2}\right)$ (Spektrofotometer-SNI 06-6989.92004), nitrate $\left(\mathrm{NO}_{3}\right)$ (Spektrofotometer-SNI 6989.792011), phosphate $\left(\mathrm{PO}_{4}\right)$ (Spektrofotometer-SNI 066989.30-2005), and alkalinity (titrate) in Laboratorium of Aquaculture Business Center. The farming business analysis was taken through direct observation and interviewing pond managers.

\section{Data Analysis}

The measure of temperature, $\mathrm{pH}$, dissolved oxygen, ammonia $\left(\mathrm{NH}_{3}\right)$, nitrite $\left(\mathrm{NO}_{2}\right)$, nitrate $\left(\mathrm{NO}_{3}\right)$, phosphate $\left(\mathrm{PO}_{4}\right)$, alkalinity, and salinity. The results were then analyzed using Pollution Index (PI) method by referring to the Ministerial Decree of Environment No. 115 of 2003. The R/C Ratio analysis was applied to analyze the business process of the $A B C$ company. All the data were processed and analyzed using Microsoft Office Excel 2007 software. The step-bystep data analysis can be explained as follows:

\section{a. Pollution Index (PI)}

An index that can determine the water quality status is the pollution index (PI). The classification of water quality using PI was first introduced by Nemerow \& Sumitomo (1970) and incorporated in the Ministerial Decree No. 1152003 as one of the standard methods to determine water quality level (Table 1). 


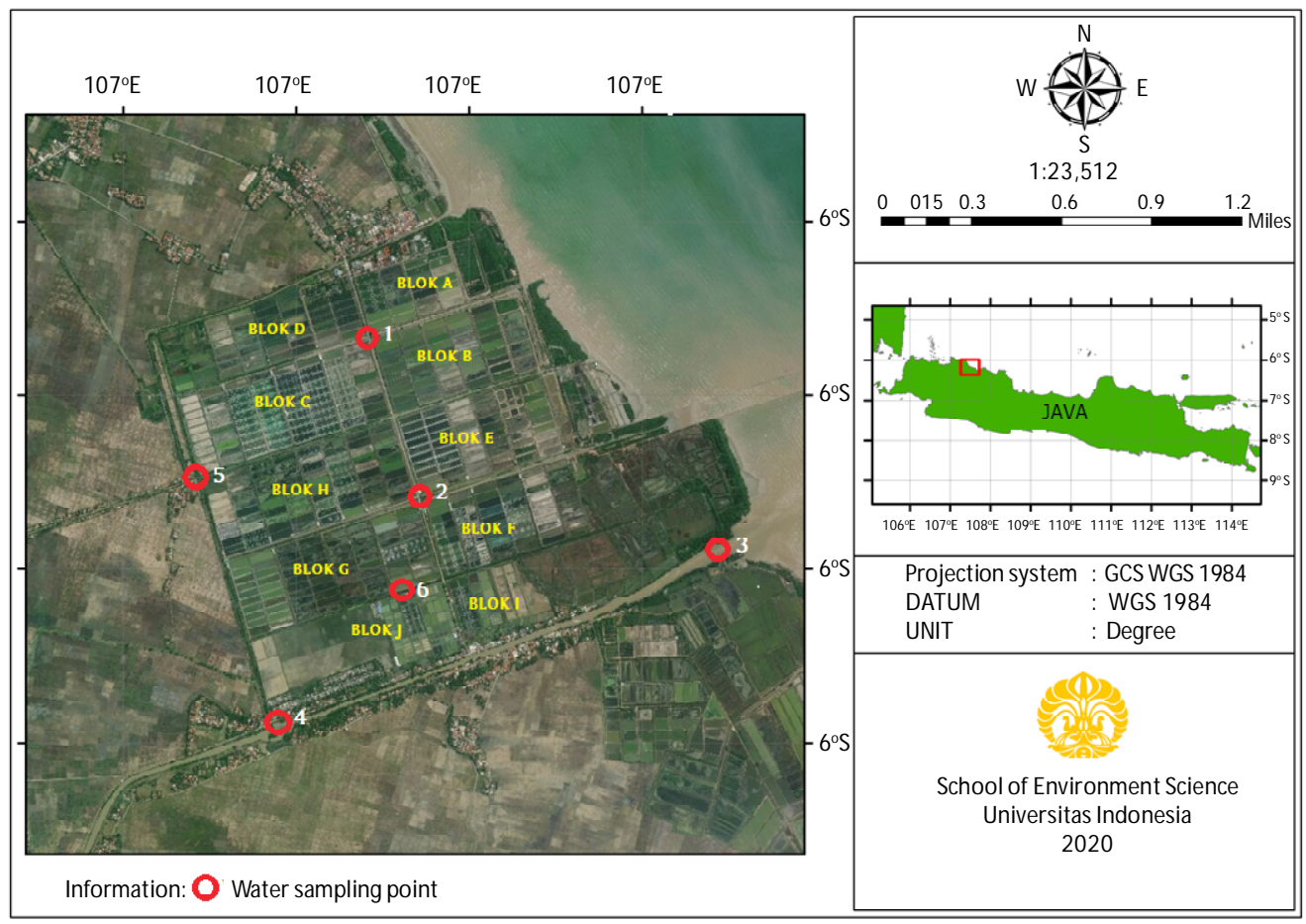

Figure 1. Location of sampling sites

This Pollution Index (PI) provides simple numerical categorization to decision-makers to assess whether the condition of a water body deteriorates due to the presence of pollutants. Pollution Index (PI) covers a variety of independent parameter groups. The Pollution Index is calculated using the formula as follows (Nemerow $\&$ Sumitomo, 1970):

$$
P I_{j}=\sqrt{\frac{\left(\frac{C_{i}}{L_{i j}}\right)_{M}^{2}+\left(\frac{C_{i}}{L_{i j}}\right)_{R}^{2}}{2} .}
$$

Information:

$$
\begin{aligned}
& \mathrm{PI}_{j} \quad=\text { Pollution index for the-j designation } \\
& \mathrm{Ci}=\text { Concentration of the-i water quality parameter }
\end{aligned}
$$

\section{b. Analysis of R/C Ratio}

Revenue Cost Ratio analysis is a value obtained from the ratio between total revenue and total production cost. This analysis is used to determine the economic profitability obtained from an aquaculture activity using the R/C Ratio 2 equation below.

$$
\mathrm{R} / \mathrm{C}=\frac{\text { Total revenue }}{\text { Total cost of production }}
$$

With criteria:

$\mathrm{R} / \mathrm{C}>1$, profitable business

$\mathrm{R} / \mathrm{C}<1$, business loss

$\mathrm{R} / \mathrm{C}=1$, effort at breakeven

\section{RESULTS AND DISCUSSION}

\section{Pollution Index (PI)}

The results of water quality measurements at six stations are presented in Figure 2.

The Aquaculture Business Center $(A B C)$ area in Karawang is bordered to the north by the North Coast of Java, the south by Cimunclak Hamlet, and the east by Ciwadas River. Surrounded by the two water bodies, it is highly likely that the shrimp farming activity might have already impacted the surrounding waters. Cultivation activities throughout the year release a continuous discharge of waste particles into the water (Zhang et al., 2019). The ponds' wastewater contains pollutants from wasted feed, fertilizer, chemicals, and metabolites excretion (Anh et al., 2010). Dauda et al. (2019) argued that aquaculture waste is usually discharged in dissolved solids and dissolved nutrients such as nitrogen and phosphorus.

The water temperature in six sampling stations shows normal ranges between $28.1-29.6^{\circ} \mathrm{C}$, meaning that the temperature is still the standard threshold of Government Regulation No 22 2021. No local external factors are affecting the water temperature, such as the cases in shrimp ponds in Indramayu Re- 
Table 1. Determination of water categories according to Pollution Index (The Ministry of Environment No. 115 2003)

\begin{tabular}{lc}
\hline \multicolumn{1}{c}{ Value of water quality index } & Category \\
\hline $0 \leq \mathrm{PI}_{\mathrm{i}} \leq 1.0$ & Water quality standards \\
$1.0<\mathrm{Pl}_{\mathrm{i}} \leq 5.0$ & Lightly polluted \\
$5.0<\mathrm{Pl}_{\mathrm{i}} \leq 10$ & Moderately polluted \\
$\mathrm{Pl}_{\mathrm{i}}>10$ & Heavily polluted \\
\hline
\end{tabular}
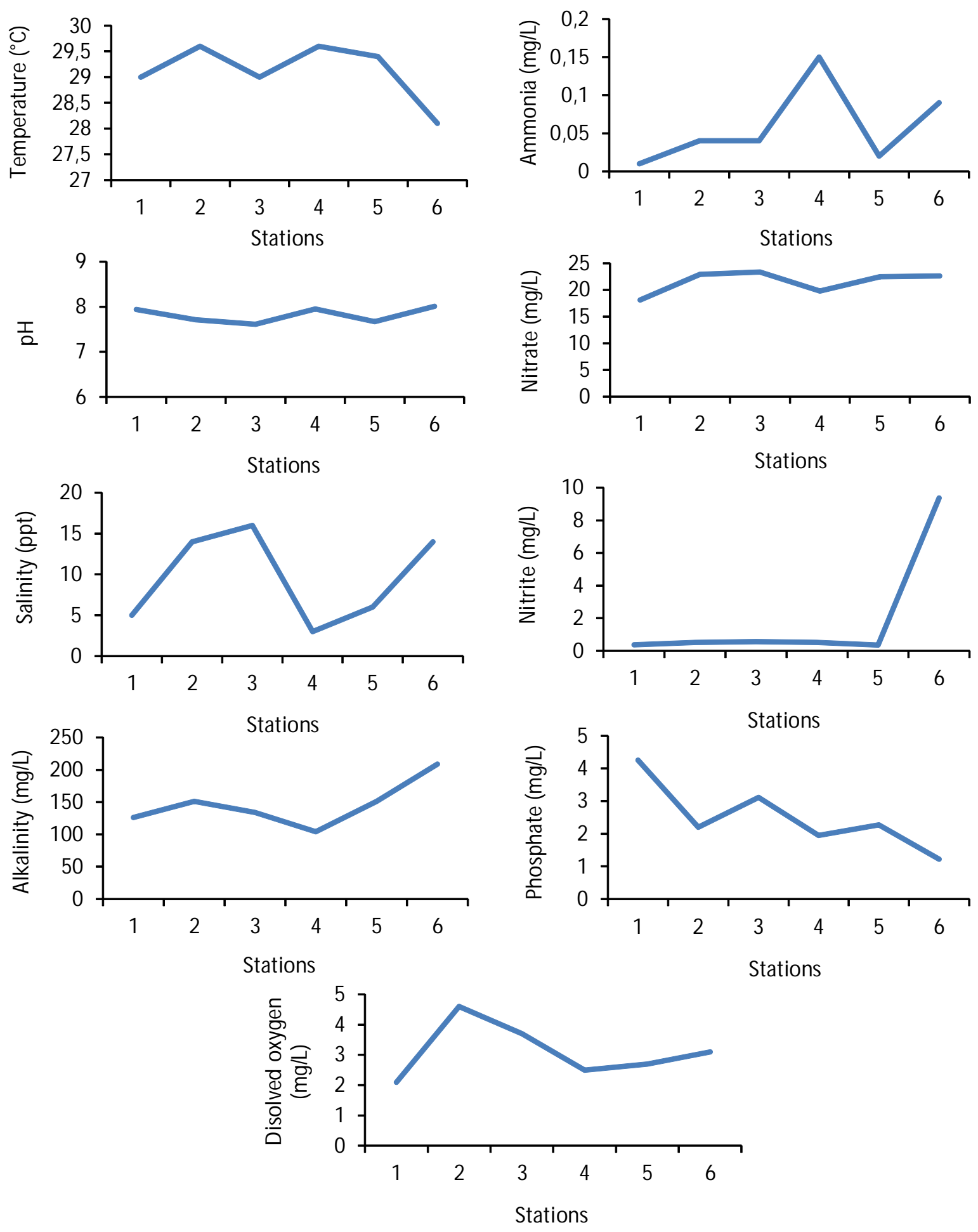

Figure 2. Water quality in $A B C$ waters 
Table 2. Collection data of water quality

\begin{tabular}{lccccccc}
\hline \multirow{2}{*}{ Parameters } & \multirow{2}{*}{$\begin{array}{c}\text { Quality } \\
\text { standard* }\end{array}$} & \multicolumn{7}{c}{ Station } \\
\cline { 3 - 8 } & & $\mathbf{1}$ & $\mathbf{2}$ & $\mathbf{3}$ & $\mathbf{4}$ & $\mathbf{5}$ & $\mathbf{6}$ \\
\hline Temperature $\left({ }^{\circ} \mathrm{C}\right)$ & $28-32$ & 29 & 29.6 & 29 & 29.6 & 29.4 & 28.1 \\
pH & $6-9$ & 7.94 & 7.71 & 7.61 & 7.95 & 7.67 & 8.01 \\
Salinity $(\mathrm{ppt})$ & $10-35$ & 5 & 14 & 16 & 3 & 6 & 14 \\
Alkalinity $(\mathrm{mg} / \mathrm{L})$ & $80-150$ & 126 & $\mathbf{1 5 1}$ & 134 & 104 & $\mathbf{1 5 1}$ & $\mathbf{2 0 9}$ \\
Ammonia $\left(\mathrm{NH}_{3}\right)(\mathrm{mg} / \mathrm{L})$ & $<0.5$ & 0.01 & 0.04 & 0.04 & 0.15 & 0.02 & 0.09 \\
Nitrate $\left(\mathrm{NO}_{3}\right)(\mathrm{mg} / \mathrm{L})$ & 20 & 18.09 & $\mathbf{2 2 . 9 3}$ & $\mathbf{2 3 . 3 8}$ & 19.8 & $\mathbf{2 3 . 4 8}$ & $\mathbf{2 2 . 6 4}$ \\
Nitrite $\left(\mathrm{NO}_{2}\right)(\mathrm{mg} / \mathrm{L})$ & 0.06 & $\mathbf{0 . 3 7}$ & $\mathbf{0 . 5 2}$ & $\mathbf{0 . 5 6}$ & $\mathbf{0 . 5 1}$ & $\mathbf{0 . 3 6}$ & $\mathbf{9 . 3 6}$ \\
Phospate $\left(\mathrm{PO}_{4}\right)(\mathrm{mg} / \mathrm{L})$ & 1 & $\mathbf{4 . 2 5}$ & $\mathbf{2 . 2}$ & $\mathbf{3 . 1 1}$ & $\mathbf{1 . 9 5}$ & $\mathbf{2 . 2 7}$ & $\mathbf{1 . 2 2}$ \\
Dissolved oxygen $(\mathrm{mg} / \mathrm{L})$ & 3 & $\mathbf{2 . 1}$ & 4.6 & 3.7 & $\mathbf{2 . 5}$ & $\mathbf{2 . 7}$ & 3.1 \\
\hline
\end{tabular}

Explanation: * Government Regulation No 22/2021 (Attached VI)

Table 3. Pollution Index (PI) Calculation Results

\begin{tabular}{|c|c|c|c|c|c|c|}
\hline \multirow{2}{*}{ PI calculation phase } & \multicolumn{6}{|c|}{ Stations } \\
\hline & 1 & 2 & 3 & 4 & 5 & 6 \\
\hline$(\mathrm{Ci} / \mathrm{Lij})_{\mathrm{M}}$ & 6.17 & 8.67 & 9.33 & 8.5 & 6 & 156 \\
\hline$(\mathrm{Ci} / \mathrm{Lij})_{R}$ & 1.68 & 1.65 & 1.8 & 1.69 & 1.48 & 18.24 \\
\hline$(\mathrm{Ci} / \mathrm{Lij})_{\mathrm{M}}^{2}$ & 38.07 & 75.17 & 87.05 & 72.25 & 36 & 24,336 \\
\hline$(\mathrm{Ci} / \mathrm{Lij})_{\mathrm{R}}^{2}$ & 2.83 & 2.73 & 3.25 & 2.85 & 2.2 & 332.81 \\
\hline$(\mathrm{Ci} / \mathrm{Lij})_{M}{ }^{2}+(\mathrm{Ci} / \mathrm{Lij})_{R}{ }^{2}$ & 40.9 & 77.89 & 90.3 & 75.1 & 38.2 & $24,668.81$ \\
\hline$\frac{(\mathrm{G} / \mathrm{Lij})_{\mathrm{M}}^{2}+(\mathrm{Ci} / \mathrm{Lij})_{\mathrm{R}}^{2}}{2}$ & 20.45 & 38.95 & 45.15 & 37.55 & 19.1 & $12,334.4$ \\
\hline$\sqrt{\frac{(\mathrm{G} / \mathrm{Lij})_{\mathrm{M}^{2}}+(\mathrm{G} / \mathrm{Lij})_{\mathrm{R}}^{2}}{2}}$ & 4.52 & 6.24 & 6.72 & 6.13 & 4.37 & 111.06 \\
\hline Pij (PI Status) & $\begin{array}{l}\text { Lightly } \\
\text { polluted }\end{array}$ & $\begin{array}{c}\text { Moderately } \\
\text { polluted }\end{array}$ & $\begin{array}{l}\text { Moderately } \\
\text { polluted }\end{array}$ & $\begin{array}{c}\text { Moderately } \\
\text { polluted }\end{array}$ & $\begin{array}{l}\text { Lightly } \\
\text { polluted }\end{array}$ & $\begin{array}{l}\text { Heavily } \\
\text { polluted }\end{array}$ \\
\hline
\end{tabular}

gency, West Java (Utojo et al., 2013), Pati ponds in Central Java (Asaf et al., 2015), and Maros ponds in South Sulawesi (Utojo et al., 2011). This temperature range is the typical value range in most areas in a tropical country such as Indonesia. According to Alberto (2016), extreme temperature changes might affect an organism's metabolic rate, altering the spatial distribution of organisms both in the ocean and the freshwater ecosystem. Furthermore, the temperature also significantly affects the growth and life of aquatic biota (Alberto, 2016).

The water's pH (acidity level) of the ABC sampling stations is normal from 7.61-8.01 and still within the threshold of Government Regulation No 222021 where normal $\mathrm{pH}$ should not be out of the range of
6-9 for aquaculture farming. Another regulation, the Ministerial Decree of Marine Affairs and Fisheries No.28/2004, also recommends that the $\mathrm{pH}$ should not be out of range 6-9 for the discharged water pond effluents in shrimp culture. This is the same as the $\mathrm{pH}$ of the waters in the Indramayu and Maros ponds (Utojo et al., 2011, 2013) and the waters in the Pati ponds, Central Java (Asaf et al., 2015). This study finding is different from the study results by Yu et al. (2020), who showed that $\mathrm{pH}$ values of 6.5 and $9.5 \mathrm{had}$ caused a significant reduction in shrimp growth. The $\mathrm{pH}$ is described as the number of hydrogen ions in water, which generally represents the acidity or alkalinity of water (Effendi, 2003). Changing in pH may affect the productivity of aquatic animals and plants. 
Therefore, $\mathrm{pH}$ is often used to indicate whether or not the waters could support the life of the aquatic animal (Effendi, 2003).

In station 1 (mixed channels A), station 4 (Ciwadas River), and station 5 (Cimunclak River), the salinity values were $5 \mathrm{ppt}, 3 \mathrm{ppt}$, and $6 \mathrm{ppt}$, respectively, which are below the suggested standard. These numbers indicate that the salinity at that stations is far below the threshold stated in the Government Regulation No 22/2021. The freshwater mass from the rivers influences the three stations' salinity levels. According to Supriadi (2001), salinity changes are often caused by rainfall and seawater masses' mixing with freshwaters, forming brackish water with unique physical characteristics.

For the alkalinity, only station Six has exceeded the threshold, where the value was $209 \mathrm{mg} / \mathrm{L}$. Station Six is the outlet channel of the pond. Effendi (2003) defines alkalinity as a buffer capacity to decrease the waters' pH. Another water quality parameter, the ammonia content, is the main parameter in determining water quality concerning nitrogen concentration in waters. Ammonia values between 0.01-0.15 $\mathrm{mg} / \mathrm{L}$ indicate that the water condition is still within the quality standard based on the PP. 22 of $2021 \mathrm{am}$ monia threshold $0.5 \mathrm{mg} / \mathrm{L}$, while the standard quality value of the Decree of the Minister of KP No. 28 of 2004 , is $<0.1 \mathrm{mg} / \mathrm{L}$. This finding is the same as the research results of Romadhona et al. (2016), who found the ammonia value ranges from $0.02-0.12 \mathrm{mg} / \mathrm{L}$ in their study sites. However, ammonia values $<0.02$ $\mathrm{mg} / \mathrm{L}$ can inhibit growth and cause tissue damage in some fish species (Wahyuningsih et al., 2020). Putri et al. (2019) stated that industrial areas, agricultural land, and residential areas are the main contributors to ammonia. High concentrations of ammonia in waters can reduce dissolved oxygen levels that eventually affect physiological and metabolic functions such as respiration (Zhang et al., 2013).

Station Two, Three, Five, and Six have exceeded the allowable nitrate concentration. The nitrate concentration was $22.93 \mathrm{mg} / \mathrm{L}, 23,38 \mathrm{mg} / \mathrm{L}, 23,48 \mathrm{mg} / \mathrm{L}$, and $22,64 \mathrm{mg} / \mathrm{L}$, respectively. Based on the Government Regulation No. 22 of 2021, the nitrate threshold is $20 \mathrm{mg} / \mathrm{L}$ for shrimp farming, while the Ministerial Decree of Environment 2004 limits the nitrate threshold for marine biota to less than $0.008 \mathrm{mg} / \mathrm{L}$ (Harianja et al., 2018; Putri et al., 2019). Shrimp culture may increase nitrate amount due to the feed and fertilizers' leftover accumulated at the pond's bottom. For instance, Harianja et al. (2018) reported that about 457 tonnes of nitrate had entered the Kembung River in Bengkalis each year due to the shrimp cultivations and crops along the river. Accord- ing to Nasir et al. (2018), agricultural, household, and aquaculture activities discharge large quantities of nutrients (N-P) along the Pangkep River, South Sulawesi. One of the factors that influence the presence of nitrate in water is the source of nitrate itself. Nitrate in water bodies can be derived from atmosphere diffusion, fixation, organic matter degradation, and organic waste disposal due to human activities (Effendi, 2003).

The concentration of nitrite has exceeded the allowable concentration as guided in the Government Regulation. In Station Six, the nitrite concentration was about $9.36 \mathrm{mg} / \mathrm{L}$. Station Six is the outlet channel of ABC's ponds. According to PP No. 222021 and KEP.28/MEN/2004, the nitrite threshold concentration is between $0.06 \mathrm{mg} / \mathrm{L}-2.5 \mathrm{mg} / \mathrm{L}$. As a comparison, Putri et al. (2019) reported that the concentration of nitrite in Banyuasin River Estuary ranged from 0.002 to $0.093 \mathrm{mg} / \mathrm{L}$, while Nasir et al. (2018) reported nitrite concentration in Pangkep ranged from 0.004 to 0.006 $\mathrm{mg} / \mathrm{L}$. Pantjara et al. (2015) reported that nitrate content in seawater and reservoirs was about $0.040 \pm$ $0.0416 \mathrm{mg} / \mathrm{L}$ and $0.045 \pm 0.0439 \mathrm{mg} / \mathrm{L}$, respectively. Therefore, the concentration of nitrite in the Aquaculture Business Center $(A B C)$ area was the highest compared to other areas. This result indicates that the Aquaculture Business Center in Karawang has been contaminated with some organic pollutants. Nitrite $\left(\mathrm{NO}_{2}\right)$ is an oxidized form of nitrogen with an oxidation number of +3 and can be found in wastewater, river water, and drainage treatment plants. Nitrite is a critical parameter in determining water quality because it is toxic when it reacts with hemoglobin in the blood, blocking the blood from binding oxygen (Effendi, 2003).

The phosphate concentration at all stations has exceeded the allowable threshold ranged between $1.22-4.25 \mathrm{mg} / \mathrm{L}$. Based on the Government Regulation PP No. 22 of 2021, phosphate's natural occurrences should not exceed $1 \mathrm{mg} / \mathrm{L}$, and regulation of KEP.28/ MEN/2004 limits the phosphate to not exceed 0.1 $\mathrm{mg} / \mathrm{L}$. The application of fertilizer during shrimp cultivation is the primary source of phosphate in the ponds. The leftover feed and fertilizer then released into the environment, increasing the phosphate and other organic matters to the river (Rawson et al., 2007). High organic matter may double the waters' primary productivity and eventually decrease dissolved oxygen (Ahmed et al., 2010). The phytoplankton and bacteria in the bottom of the pond may reduce the phosphate concentration since they can absorb phosphate and use it in their metabolic process. The absorption of phosphate can also occur in the pond's bottom sludge if there is $\mathrm{Ca}_{2}{ }^{+}$or $\mathrm{Fe}_{3}{ }^{+}$that may help absorb the phosphate. The content of orthophosphate 
in water is often used to indicate the level of primary productivity of waters. Phosphate in inorganic form is assimilated by phytoplankton and circulates in estuary waters (Supriadi, 2001).

Dissolved oxygen (DO) contents in stations One, Four, and Five are the lowest DO level compared to the other stations. The DO concentration was 2.1 $\mathrm{mg} / \mathrm{L}, 2.5 \mathrm{mg} / \mathrm{L}$, and $2.7 \mathrm{mg} / \mathrm{L}$, respectively. Based on the Government Regulation No. 22 of 2021 and KEP.28/MEN/2004, the limit of DO in aquatic farming should not exceed $3 \mathrm{mg} / \mathrm{L}$. Interestingly, based on the results, the low DO contents occurred when the salinity concentration was low. This situation contradicts the study results conducted by Maicá et al. (2014), who found that the higher the salinity, the lower the dissolved oxygen. It is argued here that the water at the three stations, which are located in rivers and mixed water tanks, is consistently influenced by the low salinity freshwater from the river. The water also has substantial organic matter concentration where oxygen is used to break down the organic material, reducing dissolved oxygen. Low dissolved oxygen in water may affect biological functions, inhibit growth, or even causing death to some aquatic organisms (Rahman et al., 2020). The concentration of oxygen in a water body will decrease due to the organic element's decomposition (Rawson et al., 2007).

The Pollution Index (PI) method has been used to determine the water quality status of the $A B C$ 's shrimp farming based on the data provided in Table 2. The results of the PI calculation are presented in Table 3. These PI values refer to the Minister of Environment Decree No. 115 of 2003, which classify that the water quality of $A B C$ shrimp farming is catego - rized as light to heavily polluted with the score of PIj $>10$. This water pollution is caused by shrimp pond activities that contribute to the high nitrogen and phosphate concentrations disposed of directly without going through a treatment process (Kawasaki et al., 2016). The water pollution level in the study site could be attributed to the lack of sufficient wastewater treatment plants provided by the company.

Nowadays, water could become "an expensive and scarce item" since anthropogenic pollutants such as domestic wastewater, agricultural waste, and shrimp farming waste have contaminated and worsened the water quality. On the other hand, the shrimp economic activity also plays an essential role in the local's economy. Harianja et al. (2018) argued that the economy should not be put on top of the ecology's concern. For instance, fish farming uses a large amount of marine and freshwater. Since the water resources are open access where anyone can utilize them, a precautionary approach regarding the resources' use should always prioritize the minimal impacts to the resources.

\section{Business Analysis}

The business analysis of the vannamei farming was calculated based on one pond per cycle with total revenue IDR 102,880,719, total cost IDR 93,869,539, and benefit IDR $9,011,180$. Therefore, the $R / C$ ratio is 1.10 , where $R / C>1$ meaning that the shrimp farming business is profitable or economically viable (Table 4). The highest cost component in the production of vaname is the cost of feed with an average price of IDR $13,000 / \mathrm{kg}$. It contributes $46,1 \%$ of the total cost, followed by the electricity $(20,5 \%$, the cost of fry $(17 \%$, pond production facilities $(13.5 \%$, and labor $(2.9 \%$.

Table 4. Business analysis of shrimp farming

\begin{tabular}{lc}
\hline \multicolumn{1}{c}{ Components } & Yield \\
\hline Land area (ha) & 0.45 \\
Densitv (shrimp/m²) & 68 \\
Amount of stocking (shrimp) & 307,056 \\
Amount of feed (kg) & 3,054 \\
Days of culture (DOC) (day) & 70 \\
Survival rate (\%) & 39.36 \\
Survive (shrimp) & 120,857 \\
Main body weight (g) & 13.18 \\
Shrimp size (shrimp/kg) & 76 \\
Production biomass (kg) & 1,593 \\
FCR & 1.92 \\
Shrimp selling price (IDR/kg) & 64,583 \\
Revenue (IDR) & $\mathbf{1 0 2 , 8 8 0 , 7 1 9}$ \\
Cost (IDR) & $\mathbf{9 3 , 8 6 9 , 5 3 9}$ \\
Benefit (IDR) & $\mathbf{9 , 0 1 1 , 1 8 0}$ \\
\hline
\end{tabular}




\section{CONCLUSION}

Some organic pollutants have contaminated shrimp farming in the Aquaculture Business Center ( $A B C$ ) area of Karawang Regency. The current pollution status water is classified from lightly to heavily polluted. Based on the R/C analysis, it can be concluded that shrimp farming is economically viable and profitable. However, this study suggests that the future profitability of the farm could be negatively affected if the level of water pollution in the area is not adequately addressed. Improving the capacity of wastewater treatment plants, efficient feeding management and following the general rules of Good Aquaculture Practices could extend the sustainability of the farming system.

\section{ACKNOWLEDGEMENTS}

The authors would like to thank Universitas Indonesia for funding this research through PUTI Grant with contract number NKB-2573/UN2.RST/HKP.05.00/ 2020. We also thank Aquaculture Business Center Karawang Regency for providing access and research support during the fieldwork.

\section{REFERENCES}

Ahmed, R., Shahabuddin, A.M., Habib, M.A.B., \& Yasmin, M. (2010). Impact of Aquaculture Practices in Naogaon District of Bangladesh. Research Journal of Fisheries and Hydrobiology, 5(2), 56-65.

Alberto, A. (2016). Analysis of the physical and chemical conditions of the vaname shrimp pond effluent (Litopenaeus vannamei) in Aquaculture Business Center Karawang, Jawa Barat. Universitas Indonesia.

Anh, P.T., Kroeze, C., Bush, S.R., \& Mol, A.P.J. (2010). Water pollution by intensive brackish shrimp farming in south-east Vietnam: Causes and options for control. Agricultural Water Management, 97(6), 872-882. https://doi.org/10.1016/ j.agwat.2010.01.018.

Asaf, R., Ratnawati, E., \& Mustafa, A. (2015). Analysis of the influence of environmental factors tambak cultivation on tambak productivity in Tayu, Pati District, Central Java Province. 2, 789-800.

Bappenas. (2014). Study of Sustainable Fisheries Management Strategies. Kementerian PPN/Bapenas Direktorat Kelautan Dan Perikanan, 120 pp.

Boyd, C. E. (2003). Guidelines for aquaculture effluent management at the farm-level. Aquaculture, 226(1-4), 101-112. https://doi.org/10.1016/S00448486(03)00471-X.
BPS. (2019). Cultivation fishery production by province and type of cultivation. Retrieved from https:/ /www.bps.go.id/dynamictable/2019/05/14/1622/ produksi-perikanan-budidaya-menurut-provinsidan-jenis-budidaya-2017.html.

Dauda, A.B., Ajadi, A., Tola-Fabunmi, A.S., \& Akinwole, A.O. (2019). Waste production in aquaculture: Sources, components and managements in different culture systems. Aquaculture and Fisheries, 4(3), 81-88. https://doi.org/10.1016/ j.aaf.2018.10.002.

De Lacerda, L.D., Vaisman, A.G., Maia, L.P., Ramos E Silva, C.A., \& Soares Cunha, E.M. (2006). Relative importance of nitrogen and phosphorus emissions from shrimp farming and other anthropogenic sources for six estuaries along the NE Brazilian coast. Aquaculture, 253(1-4), 433-446. https:// doi.org/10.1016/j.aquaculture.2005.09.005.

Effendi, H. (2003). Study of Water Quality for Management of Water Resources and Environment. Yogyakarta: Kanisius.

FAIRR. (2019). Shallow returns ? ESG risks and opportunities in aquaculture. 15. Retrieved from www.fairr.org.

FAO. (2018). The State of World Fisheries and Aquaculture 2018 - Meeting the sustainable development goals. In FAO. Retrieved from http:// www.fao org/state-of-fisheries-aquaculture.

Galappaththi, E.K., \& Berkes, F. (2015). Drama of the commons in small-scale shrimp aquaculture in northwestern Sri Lanka. International Journal of the Commons, 9(1), 347-368. https://doi.org/ 10.18352/ijc.500.

Government Regulation RI No. 22. (2021). Government Regulation Number 22 of 2021 concerning Guidelines for Environmental Protection and Management. State Secretariat of the Republic of Indonesia, Vol. 1, p. 483. Retrieved from http:// www.jdih.setjen.kemendagri.go.id/.

Hadie, W. \& Hadie, L.E. (2017). Analysis of the Aquaculture System to Support a Policy of Sustainable Shrimp Production. Jurnal Kebijakan Perikanan Indonesia, 9(1), 51-60.

Harianja, R. S. M., Anita, S., \& Mubarak, M. (2018). Analysis of pollution load in shrimp ponds around the Kembung River, Bantan Bengkalis District. Dinamika Lingkungan Indonesia, 5(1), 12. https:// doi.org/10.31258/dli.5.1.p.12-19.

Hidayatillah, Y. (2017). The social impact of shrimp pond industry on the environment in Andulang Village, Sumenep Regency. Jurnal Teori Dan Praksis Pembelajaran IPS, 21-26. 
Imamah, I.L., Hartoyo, S., Syaukat, Y., \& Utami K,S. (2013). The total productivity factor of the pond business is related to pond pollutants in Karawang Regency. Agribusiness Journal, 7(1), 35-58. https:// doi.org/10.15408/aj.v7i1.5169.

Jayanthi, M., Thirumurthy, S., Muralidhar, M., \& Ravichandran, P. (2018). Impact of shrimp aquaculture development on important ecosystems in India. Global Environmental Change, 52(March), 1021. https://doi.org/10.1016/ j.gloenvcha.2018.05.005.

Kemenko Marves. (2020). Coordinating Minister Luhut Asks for Speeding Up Vaname Shrimp Export Program. Retrieved from Kementerian Koordinator Bidang Kemaritiman dan Investasi website: https://maritim.go.id/menko-luhut-mintaprogram-peningkatan-ekspor-udang-vaname/.

KKP. (2018). Shrimp farming is still very potential. Retrieved from https://kkp.go.id/djpb/artikel/8688kkp-budidaya-udang-masih-sangat-potensial.

KKP. (2020). KKP Prepares Strategies for Facing Aquaculture Challenges in 2020. Retrieved from Kementerian Kelautan dan Perikanan website: https://kkp.go.id/djpb/artikel/17871-kkp-siapkanstrategi-hadapi-tantangan-akuakultur-di-tahun2020.

Maicá, P.F., de Borba, M.R., Martins, T.G., \& Wasielesky, W. (2014). Effect of salinity on performance and body composition of Pacific white shrimp juveniles reared in a super-intensive system. Revista Brasileira de Zootecnia, 43(7), 343-350. ht t p s://doi.org/10.1590/S151635982014000700001.

Minister of Environment Number 115. (2003). Decree of the Minister of Environment Number 115 concerning Guidelines for Determining Water Quality Status. Jakarta: State Minister for the Environment, p. 1-15.

Minister of Marine Affairs and Fisheries No. 28. (2004). Decree of the Minister of Marine Affairs and Fisheries of the Republic of Indonesia Number KEP.28/ MEN/2004 concerning General Guidelines for Cultivating Shrimp in Ponds, 26 pp.

Mitro, S., Khatun, R., \& Baten, M. (2014). Socio-Economic and Environmental Impacts of Shrimp Culture in Some Selected Areas of Bagerhat District. Journal of Environmental Science and Natural Resources, 7(1), 265-269. https://doi.org/10.3329/ jesnr.v7i1.22181.

Nasir, A., Baiduri, M. A., \& Hasniar. (2018). Nutrient N-P in Coastal Waters of Pangkep, South Sulawesi. Jurnal IImu dan Teknologi Kelautan Tropis, 53(9), 1689-1699.
Nemerow, N.L. \& Sumitomo, H. (1970). Benefits of Water Quality Enhancement. Report No. 16110 DAJ, prepared for the US Environmental Protection Agency, December 1970. Syracuse University, Syracuse, NY.

Páez-Osuna, F. (2001). The environmental impact of shrimp aquaculture: A global perspective. Environmental Pollution, 112(2), 229-231. https://doi.org/ 10.1016/S0269-7491(00)00111-1.

Pantjara, B., Syafaat, M. N., \& Kristanto, A. H. (2015). Effect of dynamical water quality on shrimp culture in the Integrated Multitropic Aquaculture (IMTA). Indonesian Aquaculture Journal, 10(1), 81. https://doi.org/10.15578/iaj.10.1.2015.81-90

Partelow, S., Senff, P., Buhari, N., \& Schlüter, A. (2018). Operationalizing the social-ecological systems framework in pond aquaculture. International Journal of the Commons, 12(1), 485-518. https://doi.org/ 10.18352/ijc.834.

Pinto, Z. (2016). Study of Coastal Community Behavior that Causes Environmental Damage (Case Study at Kuwaru Beach, Poncosari Village, Srunjuk District, Bantul Regency, DIY Province). Jurnal W ilayah Dan Lingkungan, 3(3), 163. https://doi.org/ 10.14710/jwl.3.3.163-174.

Putri, W. A. E., Purwiyanto, A. I. S., Fauziyah, ., Agustriani, F., \& Suteja, Y. (2019). Conditions of Nitrate, Nitrite, Ammonia, Phosphate and Bodies in the mouth of the Banyuasin River, South Sumatra. Jurnal IImu Dan Teknologi Kelautan Tropis, 11(1), 65-74. https://doi.org/10.29244/ jitkt.v11i1.18861.

Rahman, A., Dabrowski, J., \& McCulloch, J. (2020). Dissolved oxygen prediction in prawn ponds from a group of one step predictors. Information Processing in Agriculture, 7(2), 307-317. https://doi.org/ 10.1016/j.inpa.2019.08.002.

Rawson, M., Chen, C., Wang, D., Yarish, C., Sullivan, J., Wang, L., \& Zhu, M. (2007). Ecosystem-based management and models in sustainable management of coastal aquaculture. Bull. Fish. Res. Agent., 19, 97-111.

Romadhona, B., Yulianto, B., \& Sudarno, S. (2016). Fluctuation of ammonia content and environmental pollution load of intensive vaname shrimp ponds with partial harvest and total harvest techniques. SAINTEK PERIKANAN: Indonesian Journal of Fisheries Science and Technology, 11(2), 84. https://doi.org/ 10.14710/ijfst.11.2.84-93.

Saha, S. K. (2017). Socio-economic and environmental impacts of shrimp farming in the south-western coastal region of Bangladesh. International Journal of Research on Land-Use Sustainability, 128-137. https://doi.org/10.13140/RG.2 
Supriadi, I. H. (2001). Tropical estuary dynamics. Oseana, XXVI(4), 1-11.

Tarunamulia, Kamariah, \& Mustafa, A. (2016). Spatial relationship between environmental quality and the presence of potentially causative phytoplankton species of HABs at extensive brackishwater ponds area in Cirebon Regency, West Java. Jurnal Riset Akuakultur, 11(2), 181-195.

Tran, N., Rodriguez, U.P., Chan, C.Y., Phillips, M.J., Mohan, C.V., Henriksson, P.J.G., ....., \& Hall, S. (2017). Indonesian aquaculture futures: An analysis of fish supply and demand in Indonesia to 2030 and role of aquaculture using the AsiaFish model. Marine Policy, 79 (November 2016), 25-32. https:// doi.org/10.1016/j.marpol.2017.02.002.

Utojo, Mustafa, A., \& Hasnawi. (2011). Site assessment of coastal areas of Maros Regency, South Sulawesi to develope environmentaly-friendly brackishwater pond culture system. Jurnal Riset Akuakultur, 6(2), 325-339.
Utojo, Mustafa, A., \& Kamariah. (2013). Evaluation of sustainable biophysical properties of windu shrimp cultivation (Penaeus monodon) in Indramayu District, West Java. Prosiding Forum Inovasi Teknologi Akuakultur (1), p. 1013-1024.

Wahyuningsih, S., Gitarama, A.M., \& Gitarama, A.M. (2020). Ammonia in Fish Cultivation Systems. Syntax Literate; Jurnal IImiah Indonesia 5(2), 112. https://doi.org/10.36418/syntax-literate.v5i2.929.

Zhang, J.Y., Ni, W.M., Zhu, Y.M., \& Pan, Y.D. (2013). Effects of different nitrogen species on sensitivity and photosynthetic stress of three common freshwater diatoms. Aquatic Ecology, 47(1), 25-35. https://doi.org/10.1007/s10452-012-9422-z.

Zhang, Y., Yu, J., Su, Y., Du, Y., \& Liu, Z. (2019). Longterm changes of water quality in aquaculturedominated lakes as revealed by sediment geochemical records in Lake Taibai (Eastern China). Chemosphere, 235, 297-307. https://doi.org/ 10.1016/j.chemosphere.2019.06.179. 